\title{
The Relationship between Destination Image, Curiosity and Destination Loyalty and the Moderator Role of Demographic Variables: A Research in Antalya Destination
}

\author{
Abdullah Uslu* \\ Akdeniz University (Turquia) \\ Ali İnanır** \\ Burdur Mehmet Akif Ersoy University (Turquia) \\ Özlem Dağdelen**** \\ Akdeniz University. Institute of Social Sciences (Turquia)
}

\begin{abstract}
The purpose of this research is to determine the relationship between the dimensions of destination image, destination curiosity and loyalty, as well as to analyze the moderating effect of demographic variables on the relationship between destination curiosity and loyalty. The survey technique has been used in the research. EFA, CFA, Path and Slope analyzes have been conducted through 397 surveys collected from foreign tourists coming to Antalya, Turkey. As a result of the study, It has been determined that there are significant relationships between the dimensions of the destination image, curiosity and loyalty. In addition, it has been determined that marital status has a moderating effect on the relationship between destination curiosity and loyalty.
\end{abstract}

Keywords: Destination Image; Destination Curiosity; Destination Loyalty; Demographic Variables; Antalya.

Relación de lealtad, curiosidad e imagen de destino y el papel de moderador de las variables demográficas: una investigación en el destino de Antalya

Resumen: El propósito de esta investigación es determinar la relación entre las dimensiones de la imagen de destino, la curiosidad de destino y la lealtad, así como analizar el efecto moderador de las variables demográficas en la relación entre la curiosidad de destino y la lealtad. La técnica de encuesta ha sido utilizado en la investigación. Los análisis de EFA, CFA, Path y de Slope se han llevado a cabo a través de 397 encuestas recolectadas de turistas extranjeros que vienen a Antalya, Turquia. Como resultado del estudio, se ha determinado que existen relaciones significativas entre las dimensiones de la imagen del destino, la curiosidad y la lealtad. Además, se ha determinado que el estado civil tiene un efecto de moderador en la relación entre la curiosidad del destino y la lealtad.

Palabras Clave: Imagen de Destino; Curiosidad de Destino; Lealtad de Destino; Variables Demograficas; Antalya.

\section{Introduction}

Tourism sector have been severely affected by the economic and financial crisis such as coronavirus (Covid-19). So it is now essential to analyze the key elements of tourist consumer behavior in destinations (Lopes, 2011). In this context, destination image is very important phenomenon because it gives ideas

* Akdeniz University (Turquía); E-mail: auslu@akdeniz.edu.tr; https://orcid.org/0000-0002-3660-7096

** Burdur Mehmet Akif Ersoy University (Turquía); E-mail: ainanir@mehmetakif.edu.tr; https://orcid.org/0000-0001-8647-3375

*** Akdeniz University. Institute of Social Sciences (Turquía); E-mail: ozdagdelen03@gmail.com; https://orcid.org/0000-0003-4747-8338 
potential tourists' behavior about destination (Tasci, 2009; Marine-Roig, 2019). In addition to this, the element of curiosity arising from the motivation of touristic activities in destinations is regarded as an important driving motivation factor that enables tourists to travel to the destination (Sharpley, 2008). Thanks to this factor, tourists travel especially in order to discover new destinations and experience the attractions there (Vincent, 2018; Ciasullo, 2019). Also, the phenomenon of loyalty, which arises from revisiting the destinations and recommending it to the relatives and friends of the tourists (Chen \& Gürsoy, 2001; Yoon \& Uysal, 2005) plays an important role in the long-term visit of the destinations by more tourists and extending the longevity of the destinations.

In this context, the aim of the research is to reveal the relationships between natural and cultural resources, infrastructure and socioeconomic context, social conditions and the environment dimensions, destination curiosity and destination loyalty, which are the sub-dimensions of the destination image of tourists visiting Antalya, Turkey. However, it is the sub-purpose of the research to reveal the relationship between destination curiosity and loyalty and to determine the moderator role of demographic factors in the relationship between destination curiosity and loyalty.

In this sense, upon examining in the literature on the relationship between destination image, curiosity and loyalty; it is observed that the studies examining the relationship between destination image and its sub-dimensions and destination loyalty appear abundantly in the literature (Bigne et al., 2001; Lee et al., 2005; Tasci, 2007; Rodriguez et al., 2008; Mcdowall \& Ma, 2010; Wang \& Wu, 2011; Hung \& Petrick, 2012; Zhang et al., 2014). It is also observed that the studies on the relationship between destination curiosity and loyalty are quite limited in the literature (Vincent, 2018; Ciasullo et al., 2019). However, it has been revealed that studies on the moderator role of demographic variables in the relationship between destination curiosity and loyalty are not included in the literature. This reveals the scientific importance of the research and its difference from other researches in order to fill this gap in the literature.

\section{Literature Review}

Within the scope of the literature review, information has been revealed by reference to the studies on destination image, curiosity and loyalty.

\subsection{Destination Image}

Destinations are national or international areas such as continents, countries, islands or towns, as well as important tourist attractions, with a good transport system and tourism facilities open to development within the region (Tosun \& Jenking, 1996: 521; Buhalis, 2000: 97; Howie, 2004: 78; İnanır, 2019: 519). The destination image, which has been first introduced by Hunt (1971), is expressed as the sum of an individual's thoughts, beliefs, ideas, impressions or feelings regarding the destinations (Crompton, 1979; Gallarza et al., 2002: 60; Kim \& Richardson, 2003: 218; İnanır, 2018: 10). According to Alcaniz et al. (2009), the destination image is the total statements that reveal what tourists know and feel about a destination.

Regarding the formation of the image in the destination, more than one researcher has conducted researches by considering different dimensions. There is no common consensus on this issue (Leisen, 2001). While some of the researchers (Baloglu \& McCleary, 1999; Baloglu \& Mangaloglu, 2001; Hernandez-Lobato et al., 2006; Çoban, 2012; Hussain \& Kumar, 2015; Wang et al., 2016; Cardoso et al., 2019) examine the creation of destination image in emotional dimensions consisting of cognitive, psychological or abstract components, functional or concrete components; some researchers (Echtner \& Ritchie, 1991; Beerli \& Martin, 2004; San Martin \& Rodriguez, 2008; Yılmaz et al., 2009; Ramkisson et al., 2011; Sun et al., 2013; Blas \& Carvajal-Trujillo, 2014) have examined the creation of destination image in dimensions such as cultural resources, infrastructure and socio-economic context, social conditions and environment. Few researchers have examined the destination image as a total image in a single dimension (Bigne et al., 2001; Prayag, 2008).

In order to determine the image in a tourist destination, it is attempted to measure the size of natural and cultural resources, to inform the tourists in the destination, and the adequacy of the direction signs, service providers and attractions. In terms of infrastructure and socio-economic conditions, the adequacy of the destination for local products, restaurants, shopping and entertainment activities and the calm of the city, the cleanliness of the air, and the local people's proximity to tourists are attempted to be measured. Finally, in social conditions and environment dimension, the environmental, traffic noise, 
exhaust gas pollution, adequacy of environmental cleanliness and price appropriateness of shopping malls and restaurants are attempted to be measured (Blas \& Carvajal-Trujillo, 2014).

\subsection{Destination Curiosity}

Curiosity is an important motivation factor for the realization of research in the process of collecting information about the general environment (Berlyne, 1960). It is also believed that curiosity is an important motivation factor that affects human behavior at every stage of life (Loewenstein, 1994). By definition, curiosity is motivated by discovery behavior, expressed as a desire to gain new knowledge and new emotional experience (Spielberger \& Starr, 1994; Litman \& Spielberger, 2003). In other words, curiosity is an element of motivational motivation that occurs when an individual understands that his knowledge is insufficient or thinks to discover something new (Vincent, 2018).

It is regarded that there are not enough studies in the literature regarding the infrastructure of curiosity. However, in terms of driving and attractive motivation factors, the curiosity that emerged from insufficient information turned out to be a driving motivation factor in research (Rittichainuwat, 2008; Phau et al., 2013). In this sense, Xu et al. (2013), who conducted research in the field of tourism, have stated that the curiosity is the first motivation element of curiosity as a result of the qualitative research carried out to discover the motivation factors in the marketing of tourism through games. Similarly, Scott (1996) has revealed that curiosity is an important driving motivation factor in seeing new places and discovering new things in participating in festival events in rural touristic destinations.

As the driving motivation factor, curiosity may be effective in tourist orientation and tourism activities through a number of socio-cultural factors, natural and artificial attractions, and economic values in touristic destinations. It is attempted to gather information about receiving and attaining knowledge on the region in order to measure the destination curiosity of the tourists during or before the touristic activities, about the idea that the targeted destination has esteemed places of attraction for the tourists and about the travel to the destination allowing the people to learn and discover different experiences (Vincent, 2018).

\subsection{Destination Loyalty}

Pan et al. (2012) stated that loyalty is a construct formed by attitudinal and conductive components. Similarly, loyalty seems to play an important role in tourists visiting the destination again and recommending it to family, relatives and friends (Riley et al., 2001; Chen \& Gürsoy, 2001; Yoon \& Uysal, 2005). The researchers in the field of tourism conducted research on the loyalty of the customers in the touristic destination for touristic products, entertainment and recreational activities throughout the destination (Selin et al., 1988; Backman \& Crompton, 1991; Baloglu, 2001; Lam \& Hsu, 2006). These studies are generally measured by behavioral, attitudinal and compound methods (Oppermann, 2000).

If the tourist is satisfied, thinks about returning and will recommend, then it means that the destination has a loyal customer (Cervera et al., 2012; Pan et al., 2012, Rodrigues Soares et al., 2019). In this context, in order to measure the loyalty of tourists in destinations; the statements are directed to the tourists to determine the recommendation of the region to different people, encouragement of relatives or friends to the region, using positive statements about the region, being able to visit the region even if the prices of the touristic products in the region increase, the status of visiting the region again in the next three years, within the next three years the state of being loyal to the destination (Oppermann, 2000; Yoon \& Uysal, 2005; Chen \& Tsai, 2007).

\subsection{Development of the Hypotheses}

It has been attempted to exhibit hypotheses by discussing the research on the relationship between destination image, curiosity and loyalty, and the moderator role of demographic variables during the development of hypotheses.

When the researches about the image of the destination in the field of tourism are examined, it is regarded that the image of the destination plays an important role in the destination choice, the decision making processes, the purchasing behavior and the accommodation place choice (Chon, 1992; Bigne et al., 2001; Tasci \& Gartner, 2007; Tasci \& Holecek, 2007; Tasci et al., 2007; Aksu et al., 2009; Sun et al., 2013). At the same time, the image of the destination has a positive effect on the loyalty that tourists feel towards the destination. Accordingly, it has been revealed in the studies that the image has an impact on the tendency of with through word of mouth (WOM) the tourists to visit the destination again and in the recommendations of the family, relatives and friends (Bigne et al., 2001; Lee et al., 2005; Rodriguez 
et al., 2008; Mcdowall \& Ma, 2010; Wang \& Wu 2011; Hung \& Petrick, 2012; Rajesh, 2013; Zhang et al., 2014; Rodrigues Soares et al., 2019). However, it is regarded that there are studies that reveal the relationship between natural and cultural resources, infrastructure and socio-economic context and social conditions and environment and destination loyalty, which are the sub-dimensions of the image (Lee et al., 2005; Mcdowall \& Ma, 2010). As observed in Figure 1, in the light of this information, the hypotheses $\mathrm{H}_{1}, \mathrm{H}_{3}$ and $\mathrm{H}_{5}$ have been developed as follows.

$H_{1:}$ Natural and cultural resources have a significant and positive effect on destination loyalty.

$H_{3}$ : Infrastructure and socio-economic context have a significant and positive effect on destination loyalty.

$H_{5}$ : Social conditions and the environment have a significant and positive effect on destination loyalty.

It is observed that there is no research in the literature that deals with the relationship between destination image and destination curiosity. However, the fact that image is a means of motivation attracting for the destinations (Baloglu \& Uysal, 1996; Baloglu \& McCleary, 1999; Denstadli \& Jacobson, 2011; Phau et al., 2013) and driving for the curiosity (Scott, 1996; Rittichainuwat, 2008), as well as the image phenomenon may be created with the feeling of curiosity (Wang et al., 2016) have given way to the idea that there may be a relationship between the destination image and destination curiosity. Hence, as can be observed in Figure 1, the hypotheses $\mathrm{H}_{2}, \mathrm{H}_{4}, \mathrm{H}_{6}$ have been developed as follows.

$\mathrm{H}_{2}$ : Natural and cultural resources have a significant and positive effect on destination curiosity.

$\mathrm{H}_{4}$ : Infrastructure and socio-economic context have a significant and positive effect on destination curiosity.

H6: Social conditions and the environment have a significant and positive effect on destination curiosity.

When the researches about destination curiosity and loyalty are examined, it is regarded that the studies on the phenomenon of curiosity, which is a driving motivation factor in the selection of destinations for exploratory purposes (Crompton, 1979), are quite limited. It has been revealed that the studies dealing with the effect of destination curiosity on destination loyalty are quite limited (Vincent, 2018; Ciasullo et al., 2019). Accordingly, the hypothesis $\mathrm{H}_{7}$ has been developed as follows to reveal the possible relationship between destination curiosity and destination loyalty shown in Figure 1.

\section{H7: Destination curiosity has a significant and positive effect on destination loyalty.}

Regarding demographic variables, Baloglu \& McCleary's research (1999) revealed a significant relationship between ages of tourists and perceptual and cognitive image. At the same time, a significant relationship has been revealed between age and the environment, which is a dimension of the image. However, a significant relationship has been revealed between the educational status of the tourists and the perceptual and cognitive image. It turned out that there is a significant relationship between the educational status of tourists and the environmental quality. Which is a dimension of the image. In addition to this, curiosity has a significant effect on tourists' travel intention in destination (Vincent, 2018). Hence, the hypotheses $\mathrm{H}_{8}, \mathrm{H}_{9}, \mathrm{H}_{10}$ in Figure 1 have been developed assuming that the relationship between destination curiosity and destination loyalty will have a moderator effect on demographic variables.

$H_{8:}$ Gender has a moderator effect on the relationship between destination curiosity and destination loyalty.

$H_{9}$ : The marital status has a moderating effect on the relationship between destination curiosity and destination loyalty.

H10: The number of visits to Antalya has a moderating effect on the relationship between destination curiosity and destination loyalty. 


\section{Method}

In the research, the survey method, which includes closed-ended statements and the statements have been prepared before, has been used as the data collection method. In the research, firstly, a literature review related to destination image and its sub-dimensions, destination curiosity and destination loyalty has been made and a survey form has been created as a result of this scan. The survey consists of 2 parts and 32 questions. In the first part, there are statements that measure the demographic information of the participants, in the second part, there are statements to measure the image of the destination, destination curiosity and destination loyalty. In this context, a scale consisting of 4 dimensions and 14 statements developed by Blas \& Carvajal-Trujillo (2014) has been used to measure the destination image dimensions of Antalya. These dimensions are named as natural and cultural resources (6 statements), infrastructure and socio-economic context (4 statements), social situations (2 statements) and environment ( 2 statements). Also, the statements (6 statements) used to determine destination curiosity have been taken from Vincent (2018) study and Yoon \& Uysal, 2005 and Chen \& Tsai (2007) research to measure destination loyalty. The Five-Point Likert Scale has been used in all items, and participants have been asked to evaluate the scales between "absolutely agree" and "strongly disagree". After the survey has been created, controls have been made by faculty members who are experts in their field and some of the image of the destination image has been corrected. After translation of the surveys by two people whose mother tongue is English and Russian after finalization, the survey questions have been determined for the pilot study as a result of a second check to avoid grammatical errors. The questionnaire was translated into Russian as the most foreign tourists coming to Antalya are Russian tourists (Number of Russian tourists coming to Antalya in 2019=7.017.657=Antalya Governorate, 2019) and most of them don't know English. In the research, pilot application has been carried out to test the clarity and comprehensibility of the survey for 60 foreign tourists who came to the hotel enterprises in Antalya center between May and June 2019. Upon the determination that the Cronbach's Alpha value $(\alpha=0.912)$ of 26 statements included in the survey scale is very reliable and that the statements are understandable and factor distributions are normal, the study has continued.

\subsection{Population and Sample of Research}

The universe of the research consists of foreign tourists coming to Antalya destination. The surveys created for the research have been conducted by one of the authors for foreign tourists who came to the Kaleiçi region of Antalya in June, July and August, and who stayed in the hotel businesses in Antalya, with a simple random sampling method. At the stage of the survey, 415 surveys have been collected in total by applying them on the tourists who want to fill them face to face and voluntarily. Almost all of the 18 surveys that have been collected have been removed from the research since they have been filled incompletely. It has been decided to carry out the research with the remaining 397 surveys. The number of foreign tourists coming to Antalya in 2019 is 15,644,108 people (Antalya Governorate, 2019) and the research population should be at least 384 in places with a $95 \%$ confidence interval (Cohen, Manion \& Morrison, 2017). Therefore, it can be said that 397 surveys collected in the research are sufficient for the sample.

\section{Findings}

In order to evaluate the research findings, it is necessary to test the lost data, extreme value, homogeneity and reliability for the raw data obtained from the surveys. Therefore, when looking at the lost data for the study, it has been determined that there have been no items left blank in the survey. Whether the data obtained is normally distributed or not is analyzed according to the result of skewness and kurtosis, and it has been observed that the skewness and kurtosis coefficients are not more than +3 and -3 and it has been concluded that the data has been distributed normally (Liu et al., 2003). According to the Kolmogorov-Smirnov test, which is another stage of the normality test, the significance level of the scale data is below 0.05 and the data does not show normal distribution. However, according to the central limit theorem, the data set with more than 40 observations converges to normal (Lumley et al., 2002). Based on this, the data of 397 surveys collected for research are assumed to be normally distributed and the analyzes have been done accordingly.

Cronbach's Alpha $(\alpha)$ values have been examined in order to ensure the structurally reliable and validity of the scales used in the study based on 397 samples. As observed in Table 2; the variable with 
the highest reliability value $(\alpha=0.911)$ among the destination image dimensions (natural and cultural resources, infrastructure and socio-economic context, social conditions and environment), which are included in the research model, is the destination curiosity variable and that the Cronbach's Alpha values $(\alpha)$ of all variables are above 0.70 and highly reliable (Kline, 2011).

\subsection{Demographic Characteristics of the Participants}

The frequency and percentage distributions of the demographic characteristics of the foreign tourists participating in the survey are presented in Table 1 below. Accordingly, it has been determined that $51.9 \%$ (203 people) of the participants are male, 48.1\% (194 people) are female, $60.2 \%$ (239 people) are married and the remaining $39.8 \%$ (158 people) are single. It is understood that $31.2 \%$ (124 people) of the foreign tourists participating in the study are in the $25-34$ age range, $27.5 \%$ (109 people) are in the $19-24$ age range, $15.9 \%$ (63 people) are in the 35-44 age range. It has been determined that more than half of the participants are university graduates with a rate of $65 \%$ (258 people). When the monthly income status is analyzed, it has been determined that $30.5 \%$ (121 persons) have an income between 4001-6000 Euros and then 20.7\% (82 people) have an income between 6001-8000 Euros and 8001-10.000 Euros. On the other hand, when the number of participants arriving in Antalya is examined, it is observed that the number of repeat tourists $(50.1 \%=199$ people $)$ and those who came for the first time $(49.9 \%=198$ people) are almost equal. When all these results are evaluated in general; it can be stated that the tourists visiting Antalya are rather very young or in the middle age group, are married, university graduates and considering the conditions of Turkey the majority has higher level of income.

Table 1: Respondent profile $(n=397)$

\begin{tabular}{|c|c|c|c|c|c|}
\hline Gender & $\mathbf{n}$ & $\mathbf{\%}$ & Education Level & $\mathbf{n}$ & $\mathbf{\%}$ \\
\hline Female & 194 & 48.1 & Secondary School & 8 & 2.0 \\
\hline Male & 203 & 51.9 & High school & 104 & 26.2 \\
\hline Marital Status & $\mathbf{n}$ & $\mathbf{\%}$ & University & 258 & 65.0 \\
\hline Married & 239 & 60.2 & Master's degree & 27 & 6.8 \\
\hline Single & 158 & 39.8 & Monthly Income & $\mathbf{n}$ & $\mathbf{\%}$ \\
\hline Age & $\mathbf{n}$ & $\mathbf{\%}$ & 2000 Euro and below & 27 & 6.8 \\
\hline $18-24$ & 48 & 12.1 & $2001-4000$ Euro & 70 & 17.6 \\
\hline $19-24$ & 109 & 27.5 & $4001-6000$ Euro & 121 & 30.5 \\
\hline $25-34$ & 124 & 31.2 & $6001-8000$ Euro & 82 & 20.7 \\
\hline $35-44$ & 63 & 15.9 & $8001-10.000$ Euro & 82 & 20.7 \\
\hline $45-54$ & 34 & 8.6 & 10001 Euro and above & 15 & 3.8 \\
\hline $55-64$ & 19 & 4.8 & Number of visits to Antalya & $\mathbf{n}$ & $\%$ \\
\hline 65 and above & 48 & 12.1 & First-time visitors & 198 & 49.9 \\
\hline & & & Repeat visitors & 199 & 50.1 \\
\hline
\end{tabular}

\subsection{Explanatory Factor Analysis (EFA)}

Initially, explanatory factor analyses have been applied to test the construct validity of the scales used in the research. In this context, factor analysis has been performed on the destination image, destination curiosity and destination loyalty variables in the research scale. KMO and Bartlett's tests have been performed to test the suitability for factor analysis. As a result of the EFA; KMO .918 and Bartlett's test $\chi 2$ value is $3158.186(\mathrm{p}<.000)$ for destination Image dimension. For destination curiosity, KMO .863 and Bartlett's test $\chi 2$ value have been determined as $1548.427(p<.000)$. All these results show that factor analysis meets the assumption (Kalayc1, 2014).

As shown in Table 3; in the research, EFA results have been firstly applied to the statements of destination image dimensions. As a result of the EFA, it has been noted that the destination image dimensions included a three-dimensional structure, the eigenvalues of the factors should be at least 
1 and the factor loads should be above 0.45 . As a result of the analysis, the ISO4 statement asked to measure the size of the infrastructure and social economic conditions within the destination image dimensions has been loaded with copies and has been removed from the analysis because it has been not collected in a single dimension. As a result of the reconstructed EFA analysis, a 3-factor structure has been obtained, which explained $70.203 \%$ of the total variance. The destination image dimensions resulting from EFA have been determined as natural and cultural resources, infrastructure and social economic conditions, social conditions and environment and factor loads have been determined as values between 0.861 and 0.523 .

As a result of the EFA, the statements related to the destination curiosity are gathered under a single dimension and the total variance explanation level is $69.204 \%$ and factor loads are between .864 and .785. Likewise, it has been observed that the statements about destination loyalty have been gathered under one dimension and the total variance explanation level has been $67.067 \%$. The factor loads of the statements that make up this variable are between .849 and .786 .

\subsection{Convergent and Discriminant Validity}

Within the scope of determining the reliability and validity of the study; CR, AVE, MaxR $(\mathrm{H})$ values have been examined (Table 2). CR (Composite Reliability) values are expected to be 0.70 and above and AVE (Average Variance Extracted) values are expected to be over 0.50 (Bryne, 2010; Hair et al., 2014). The CR value being greater than 0.70 indicates that the internal consistency of the factors is high, and the AVE being value higher than 0.50 indicates that there is a sufficient level of variance explained by the variables associated with the factors (Fornell \& Larcker, 1981). In order to ensure discriminant validity, MaxR $(\mathrm{H})$ (Maximum H Reliability) value should be higher than $\mathrm{CR}$ value (Hu \& Bentler, 1999). At the same time, the square root of the AVE value of a latent variable must be greater than the correlation values of that variable with other variables (Fornell \& Larcker, 1981; Hair et al., 2014).

Table 2: Convergent and discriminant validity, Cronbach's alpha (a) values

\begin{tabular}{|c|c|c|c|c|c|c|c|c|c|}
\hline & $\boldsymbol{\alpha}$ & CR & AVE & MaxR(H) & NCR & ISO & SOCE & LOY & CUR \\
\hline NCR & 0.883 & 0.858 & 0.601 & 0.858 & $\mathbf{0 . 7 7 5}$ & & & & \\
\hline ISO & 0.797 & 0.846 & 0.525 & 0.922 & 0.818 & $\mathbf{0 . 7 2 5}$ & & & \\
\hline SOCE & 0.879 & 0.911 & 0.773 & 0.957 & 0.616 & 0.705 & $\mathbf{0 . 8 7 9}$ & & \\
\hline LOY & 0.904 & 0.899 & 0.597 & 0.969 & 0.643 & 0.784 & 0.746 & $\mathbf{0 . 7 7 3}$ & \\
\hline CUR & 0.911 & 0.911 & 0.632 & 0.977 & 0.583 & 0.802 & 0.764 & 0.811 & $\mathbf{0 . 7 9 5}$ \\
\hline
\end{tabular}

$\mathrm{NCR}=$ Natural and Cultural Resources, ISO = Infrastructure and Socioeconomic Context, SOCE $=$ Social Conditions and the Enviroment, LOY=Destination Loyalty, CUR= Destination Curiosity, CR= Composite Reliability, AVE= Average Variance Extracted, Max $\mathrm{R}(\mathrm{H})=$ Maximum H Reliability and Diagonal values written in bold are square roots of AVE values.

When Table 2 is examined, it is determined that the lowest CR value calculated for latent variables is 0.846 and the lowest $\mathrm{AVE}$ value is 0.525 , and it is understood that the assumptions of the convergent validity are provided. It is observed that $\operatorname{MaxR}(\mathrm{H})$ value of each latent variable that will be included in the structural model for discriminant validity is also higher than $\mathrm{CR}$ value. In addition, it is understood that the correlation values between the square roots of the AVE value and the variables are acceptable, thereby ensuring the discriminant validity for all latent variables. Likewise, in Table 2, it is stated that the correlation values between all the dimensions that make up the model are less than ( $r>0.85)$, so that the dimensions in the model are separate structures, discriminant validity is provided, and relationships between variables can be researched (Raykov \& Marcoulides, 2006).

\subsection{Measurement Model of the Research}

By examining the relationship between destination image dimensions, destination curiosity and destination loyalty used in the research model, it has been tested with CFA analysis whether the first condition of modeling has been met and Maximum Likelihood method has been used in CFA application. 
CFA is applied to determine whether the scale and structures based on a developed or theoretical basis are verified with data and to what extent the variables fit the hypothetical theoretical structure (Alpar, 2013). With fit indices, it is determined how well the predetermined models explain the data. A wide variety of fit indices are referenced in CFA. For these fit indices, the Chi-Square Fit test $\left(\Delta \chi^{2} \leq 5\right)$ is often root mean square error of approximation (RMSEA $\leq 0.080$ ), Goodness of Fit Index (GFI $\geq .80$ ), (Adjusted Goodness of Fit Index: AGFI 80.80), comparative fit index (CFI $\geq 0.90$ ), incremental fit index (IFI $\geq 0.90$ ) values are used and acceptable goodness of fit values (Kline, 2011; Ho, 2014; Hair et al., 2014).

As a result of the CFA analysis performed to test the construct validity of the scales used, it has been determined that the observed variables have been associated with the latent variables to which they have been linked, and the covariance values between the variables are less than $\mathrm{r}<.85$, and the relationships between all variables are significant at the level of $\mathrm{p}<0.05$.

Table 3: Explanatory factor analysis (EFA) and measurement model (CFA) values

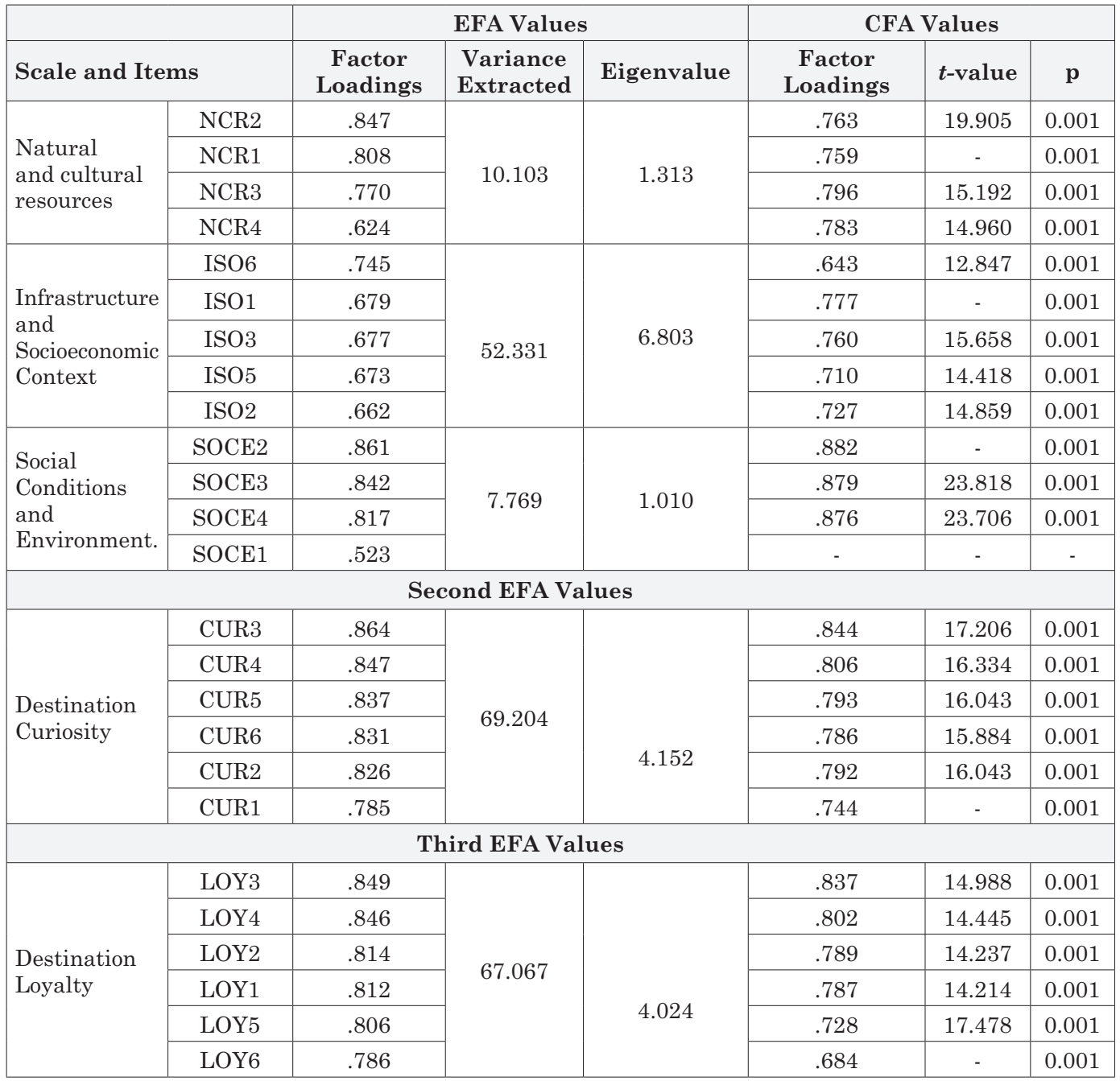

Note 1: Extraction Method = Principal Component Analysis; Rotation Method: Varimax Rotation

Note 2: Goodness-of-fit statistics of $\mathrm{CFA}=\Delta \chi 2=1834.650$; d.f. $=720 ; \chi 2 /$ d.f. $=2.548$; RMSEA $=0.044$ CFI $=0.919$; $\mathrm{GFI}=0.837 ; \mathrm{IFI}=0.919$. 
According to Table 3; in the research, EFA has been first performed on the destination image dimensions, and then explanatory factor analyzes have been made for the destination curiosity and destination loyalty dimensions. Afterwards, CFA has been performed on all variables to be included in the model and it has been removed from the model because the factor load of SOCE1 statement has been low and decreased the goodness of fit values of the model and it has been determined that all the remaining statements had a factor much higher than 0.50 (Kalayc1, 2014). In order to increase the goodness of fit values in CFA, NCR1 (e1) and NCR2 (e2), ISO5 (e9) and ISO6 (e10), LOY5 (e25) and LOY6 (e26) have been corrected and goodness of fit values and standardized values have been improved. Finally, the goodness of fit values of CFA are $\Delta \chi_{2}=1834.650$; d.f. $=720 ; \chi 2$ / d.f. $=2,548$; RMSEA $=0.044 ; \mathrm{CFI}=0.919 ; \mathrm{GFI}=0.837 ; \mathrm{IFI}=0.919$. These results indicate that CFA has adequate goodness of fit values (Hair et al., 2014).

\subsection{Testing the Research Model}

After verification of measurement models, the relationships between the variables used in the study have been tested through the structural model. Within the scope of the structural model analysis, 7 different hypotheses have been analyzed in order to determine the effects of natural and cultural resources, infrastructure and socio-economic context, social conditions and environmental dimensions, which are the sub-dimensions of the destination image, on destination curiosity and destination loyalty, and the effects of destination curiosity on destination loyalty. The path diagram of the findings obtained as a result of the structural model realized for all these purposes is indicated in Figure 1. In addition, 3 hypotheses have been tested in order to determine whether the demographic characteristics (gender, marital status and number of visits to Antalya) of foreign tourists coming to Antalya have a moderator effect in the relationship between destination curiosity and destination loyalty.

Figure 1: The conceptual model of the study and standardized values

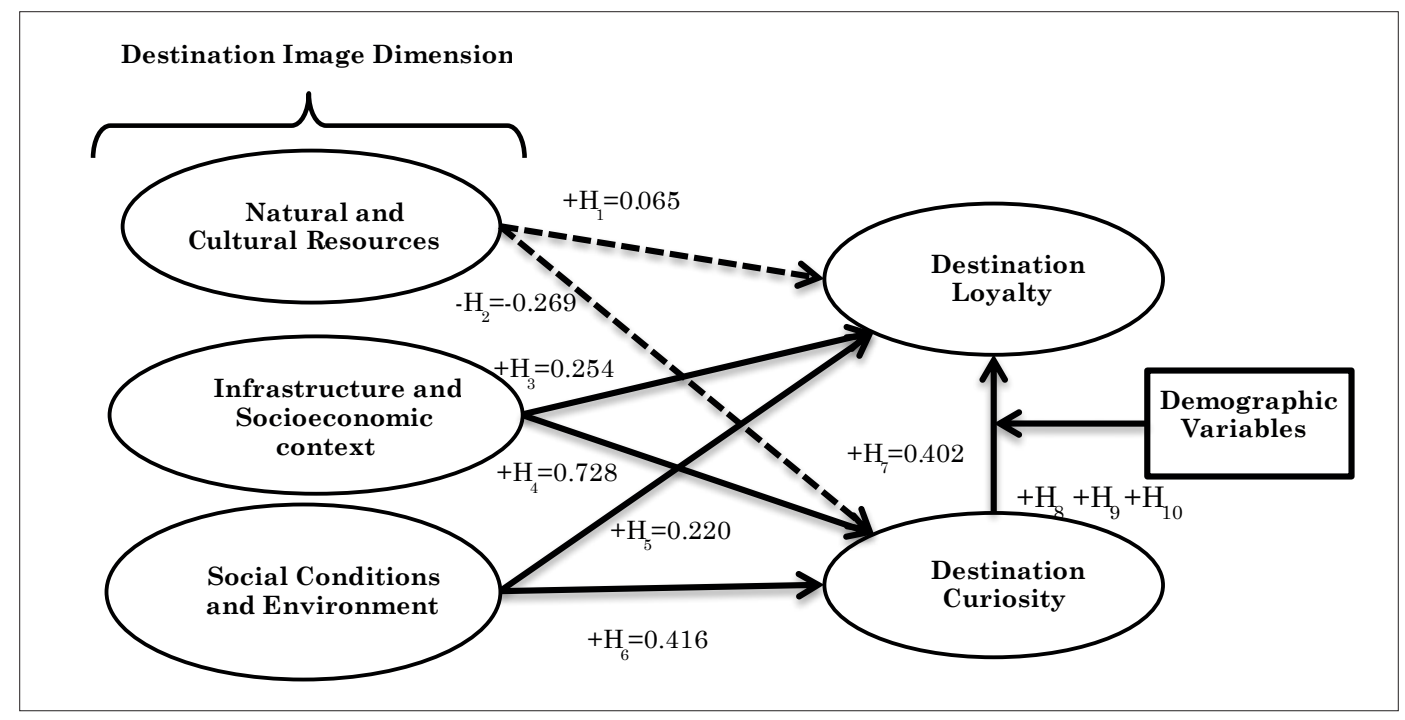

As observed in the path diagram in Figure 1; it has been determined that infrastructure and socio-economic context, social conditions and environmental dimensions, which are the sub-dimensions of the destination image, have positive effects on destination curiosity and destination loyalty. Similarly, it has been determined that the curiosity of the destination has positive effects on destination loyalty. However, it has been determined that the size of natural and cultural resources does not have a significant effect on destination curiosity and destination loyalty. In the model in Figure 1, it is regarded that the variance explanation rate for destination curiosity is $74.5 \%\left(\mathrm{R}^{2}=0.745\right)$ and the variance explanation rate for destination loyalty is $73.1 \%\left(\mathrm{R}^{2}=0.731\right)$. 
In Table 4 and Figure 1, it is observed that the t values between infrastructure and socioeconomic context and destination curiosity, two of the sub-dimensions of the destination image; social conditions and environment dimension and destination loyalty and destination curiosity and destination curiosity and destination loyalty are higher than 2.56 and in the significance level of $\mathrm{p}<0.001$ (Schumacker \& Lomax, 2010), the t values between the infrastructure and socioeconomic context and destination loyalty are higher than 2.56 and in the significance level of $p<0.001$; however, the $\mathrm{t}$ values in the relationship between natural and cultural resources and destination curiosity and destination loyalty are lower than 1.96 and not at the significance level of $p<0.001$ (Schumacker \& Lomax, 2010). Correction has been made between LOY5 (e25) and LOY6 (e26) to improve the goodness of fit of the structural model. Finally, when looking at the goodness of fit values for road analysis regarding the significance of the structural model; it is observed that $\Delta \chi 2=1700.482$; d.f. $=717 ; \chi 2$ d.f. $=2.372 ;$ RMSEA=0.042; $\mathrm{CFI}=0.928 ; \mathrm{GFI}=0.848 ; \mathrm{IFI}=0.929$ and these values are acceptable goodness of fit (Hair et al., 2014).

Table 4: Results of path analyses and hypotheses

\begin{tabular}{|c|c|c|c|c|c|}
\hline Hypotheses & $\begin{array}{c}\text { Path } \\
\text { Analyses }\end{array}$ & $\begin{array}{c}\text { Standardized } \\
\text { Loadings }\end{array}$ & $\boldsymbol{t}$-value & $\mathbf{p}$ & Results \\
\hline$+\mathrm{H}_{1}$ & $\mathrm{NCR} \rightarrow \mathrm{LOY}$ & 0.065 & 0.731 & .465 & $\mathrm{X}$ \\
\hline$+\mathrm{H}_{2}$ & $\mathrm{NCR} \rightarrow \mathrm{CUR}$ & -0.269 & -2.979 & $0.003^{* *}$ & $\mathrm{X}$ \\
\hline$+\mathrm{H}_{3}$ & $\mathrm{ISO} \rightarrow \mathrm{LOY}$ & 0.254 & 2.017 & $0.044^{*}$ & $\sqrt{ }$ \\
\hline$+\mathrm{H}_{4}$ & $\mathrm{ISO} \rightarrow \mathrm{CUR}$ & 0.728 & 6.583 & $0.001^{* * *}$ & $\sqrt{ }$ \\
\hline$+\mathrm{H}_{5}$ & $\mathrm{SOCE} \rightarrow \mathrm{LOY}$ & 0.220 & 3.434 & $0.001^{* * *}$ & $\sqrt{ }$ \\
\hline$+\mathrm{H}_{6}$ & SOCE $\rightarrow$ CUR & 0.416 & 6.777 & $0.001^{* * *}$ & $\sqrt{ }$ \\
\hline$+\mathrm{H}_{7}$ & $\mathrm{CUR} \rightarrow \mathrm{LOY}$ & 0.402 & 4.350 & $0.001^{* * *}$ & $\sqrt{ }$ \\
\hline
\end{tabular}

Note $1: * * * p<0.001, * * \mathrm{p}<0.01, * \mathrm{p}<0.05$,

Note 2: Goodness-of-fit statistics of Path Analysis: $\Delta \chi 2=1700.482$; d.f. $=717 ; \chi 2 /$ d.f. $=2.372 ;$ RMSEA $=0.042$; $\mathrm{CFI}=0.928 ; \mathrm{GFI}=0.848 ; \mathrm{IFI}=0.929$.

When the research model in Figure 1 and the hypothesis results in Table 4 are analyzed, it is observed that there are no positive effects on the destination loyalty and destination curiosity of natural and cultural resources among the destination image sub-dimensions $\left(\mathrm{H}_{1}: \beta=0.065, t=0.731, \mathrm{p}=0.465 ; \mathrm{H}_{2}\right.$ : $\beta=-0.269, t=-2.979, \mathrm{p}=0.003)$. Therefore, the hypotheses $\mathrm{H}_{1}$ and $\mathrm{H}_{2}$ previously developed have been not supported. Infrastructure and socio-economic conditions have positive and significant effects on destination loyalty $\left(\mathrm{H}_{3}: \beta=0.254, t=2.017, \mathrm{p}=0.044\right)$ and destination curiosity $\left(\mathrm{H}_{4}: \beta=0.728, t=6.583\right.$, $\mathrm{p}=0.001$ ). Therefore, the hypotheses $\mathrm{H}_{3}$ and $\mathrm{H}_{4}$ hypotheses have been supported. Similarly, positive and significant effects of social conditions and environmental dimension on destination loyalty $\left(\mathrm{H}_{5}: \beta=0.220\right.$, $t=3.434, \mathrm{p}=0.001)$ and destination curiosity $\left(\mathrm{H}_{6}: \beta=0.416, t=6.777, \mathrm{p}=0.001\right)$ have been determined $\mathrm{H}_{5}$ and $\mathrm{H}_{6}$ hypotheses have been supported accordingly. Finally, it has been concluded destination curiosity has a positive and significant effect on destination loyalty $\left(\mathrm{H}_{7}: \beta=0.402, t=4.350, \mathrm{p}=0.001\right)$. Thus, the previously developed $\mathrm{H}_{7}$ hypothesis has been also supported.

The standardized beta $(\beta)$ coefficients in the structural model indicate the magnitude of the effect of one variable on another variable. It has been observed that the standardized beta $(\beta)$ coefficients have small effects below 0.10 , and when they are above 0.50 , beta coefficients between two values have moderate effects (Kline, 2011). Accordingly, it is regarded that the effects in all these hypotheses have a medium $\left(\mathrm{H}_{3}, \mathrm{H}_{5}, \mathrm{H}_{6}, \mathrm{H}_{7}\right)$ and a high level $\left(\mathrm{H}_{4}\right)$ effect.

AMOS program has been used to determine the moderator effect of demographic variables in the effect of destination curiosity and destination loyalty. Before the analysis, the destination curiosity value, which is the forecast variable, has been standardized. As observed in Table 5; as a result of the road analysis with the observed variables, Slope difference test has been performed in order to see whether 
the differences between the regression coefficients $(\beta)$ occurring according to categorical variables are significant and the results are displayed in Table 5.

Table 5: Slope Difference Tests

\begin{tabular}{|c|c|c|c|c|c|c|}
\hline & \multicolumn{2}{|c|}{ Marital Status } & \multicolumn{2}{c|}{ Gender } & \multicolumn{2}{c|}{$\begin{array}{c}\text { Number of visits } \\
\text { to Antalya }\end{array}$} \\
\hline & Married & Single & Male & Female & $\begin{array}{c}\text { First } \\
\text { time } \\
\text { visitors }\end{array}$ & $\begin{array}{c}\text { Repeat } \\
\text { visitors }\end{array}$ \\
\hline Number of Samples & 239 & 158 & 203 & 194 & 198 & 199 \\
\hline $\begin{array}{c}\text { Regression Coefficients } \\
\text { ( } \beta \text { ) }\end{array}$ & 0.822 & 0.556 & 0.756 & 0.722 & 0.723 & 0.760 \\
\hline Standard Error & 0.036 & 0.068 & 0.047 & 0.048 & 0.045 & 0.052 \\
\hline t values & \multicolumn{2}{|c|}{3.767} & \multicolumn{2}{c|}{0.507} & \multicolumn{2}{c|}{0.585} \\
\hline p values ( *p<0.001) & \multicolumn{2}{|c|}{$\mathbf{0 . 0 0 0 *}$} & \multicolumn{2}{c|}{0.612} & \multicolumn{2}{c|}{0.559} \\
\hline
\end{tabular}

According to these results in Table 5 ; it has been revealed that the marital status (Married: $\beta=0.822$, Single: $\beta=0.556, t=3.767, p=0.000$ ), which is among categorical variables, has a moderator effect on the influence of destination curiosity of foreign tourists coming to Antalya on destination loyalty. Therefore, the hypothesis $\mathrm{H}_{9}$,"the marital status has a moderating effect on the relationship between destination curiosity and destination loyalty", has been supported. On the other hand, it has been determined that the effect of foreign tourists' destination curiosity on destination loyalty does not affect the gender and the number of visits to Antalya. Hence, the hypotheses $\mathrm{H}_{8}$ and $\mathrm{H}_{10}$ are not supported.

In order to test whether the results obtained from the hypothesis tests are valid and reliable, this interaction (moderator effect) should be shown with the Slope graph (www.jeremydawson.com, 2016). As seen in Figure 2; this Slope test reveals whether the relationship between destination curiosity and destination loyalty depends on the marital status of tourists.

Figure 2: Graphical Diagram of the moderating effect the marital status

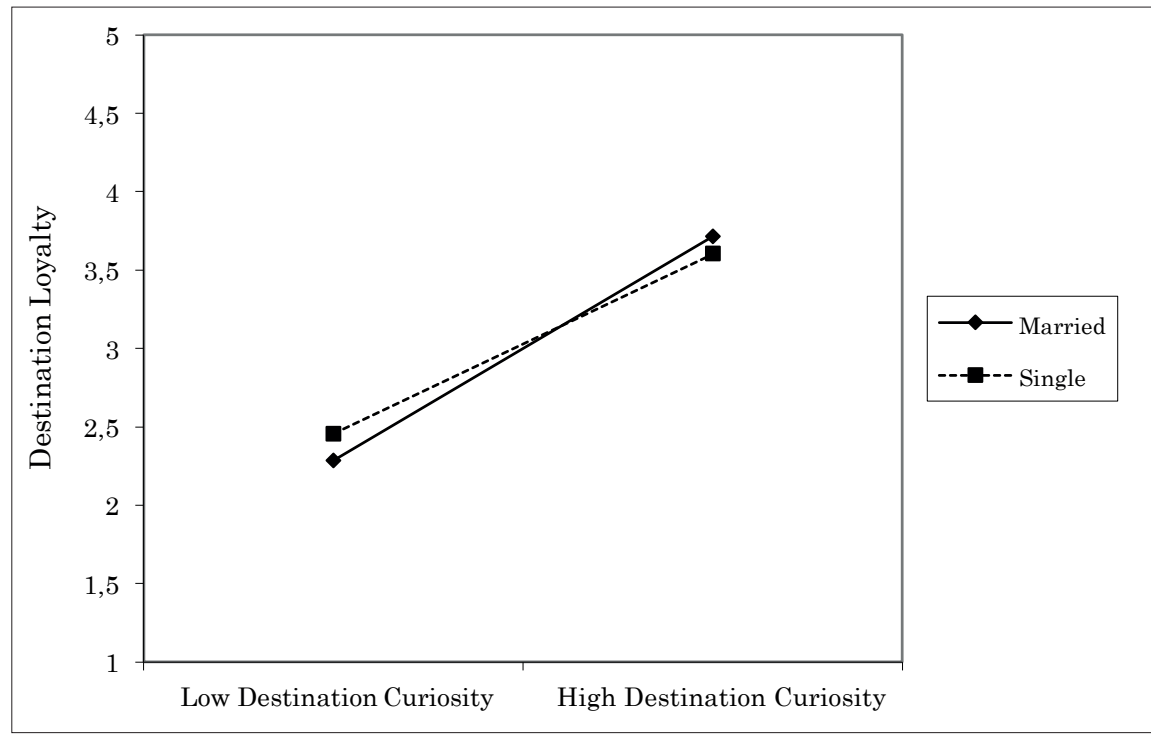


In the case where the destination curiosity is low and high in order to determine the form and direction of the foreign tourists who come to Antalya with the destination curiosity and the effect on the destination loyalty, the views of the married and single individuals regarding the destination loyalty are graphically shown in Figure 2. Graph drawing for binary categorical variable has been analyzed with Slope test. As a result of the slope test, the relationship between foreign tourists' destination curiosity and destination loyalty is positive in both married and single individuals. It is consequently observed that, when married tourists have a high destination curiosity, they have more destination loyalty than singles.

\section{Discussion and Conclusions}

The destination image, which has emerged as a general picture of the destination in the minds of tourists, may reveal the idea of tourists, especially the curiosity towards the destination, except revisiting the destination or recommending it to their relatives. In this sense and in line with the purpose of the research, 10 hypotheses have been generated in order to determine the effects between natural and cultural resources, infrastructure and socioeconomic context, social conditions and environmental dimensions, which are the sub-dimensions of the destination image, on the destination curiosity and destination loyalty and to test the moderator effects of foreign tourists (gender, marital status and number of visits to Antalya) in the relationship between destination curiosity and destination loyalty and 6 of these hypotheses have been supported.

While the image of the destination image perceived by foreign tourists coming to Antalya is mostly dealt with in terms of emotional and cognitive image in the literature, as a result of the analyzes carried out in this study, natural and cultural resources, infrastructure and socio-economic context and social situations and environment have been determined as 3 dimensions and with the confirmatory factor analysis, this three-dimensional structure has been confirmed together with other variables that entered the model. According to the findings obtained in the research; it has been determined that the size of natural and cultural resources, which constitute the destination image, does not affect destination curiosity and destination loyalty. These findings are similar to the results of the studies by Blas \& Carvajal-Trujillo (2014). Infrastructure and socio-economic context, social conditions and environment dimensions, which are other sub-dimensions of the destination image, have been found to increase destination curiosity and destination loyalty. This correlates to the studies by Bigne et al. (2001), Lee et al. (2005), Mcdowall \& Ma (2010), Zhang et al. (2014), Rodrigues Soares et al. (2019). Another important result found in this study is that the curiosity of the destination has increased the loyalty of the destination. This conclusion is consistent with the conclusion in the research by Vincent (2018), Ciasullo et al. (2019) that destination curiosity is effective on the tourists' behavior to revisit.

On the other hand, as another important finding of the study, it has been revealed that marital status, which is a categorical variable, has a moderator effect on the influence of destination curiosity of foreign tourists coming to Antalya on destination loyalty. Accordingly, the moderator effect of the married and single individuals among tourists is positive. In the case of low destination curiosity, married tourists have more destination loyalty than single individuals, while in the case of high destination curiosity they have relatively less destination loyalty than single individuals. On the other hand, it has been determined that gender and the number of visits to Antalya have no effect on the relationship between destination curiosity and destination loyalty. This result is partially similar to the study by Baloglu \& McCleary (1999) in terms of the effect of demographic variables (age,educational status) on destination image.

As a result of this study were obtained from the mass tourists who came for the purpose of sea, sand and sun. If it is done for individual tourists coming for culture, sports, business and alternative tourism activities, it may be thought that different results will appear between destination image and destination loyalty according to the demographic variables (especially the marital status). Although it has many tourism diversity in Antalya, it is a destination that stands out with its sea, sand and sun tourism. It can be thought that different demographic variables will play a role in the relationship between tourists' destination image and curiosity and destination loyalty in the destinations where culture or alternative tourism activities are mostly performed.

According to the World Tourism Organization (2007), in the 2020s, tourists will act with the feeling of trying the untested, discovering the undiscovered and being more curious. In this sense, trying to create a different destination image that will increase the curiosity of the tourists will gain an advantage over 
the competition. Therefore, local administrators and tourism professionals should strive to increase the attractiveness of the destinations and to improve the image of the destination positively. On the other hand, they should look for ways to offer different activities and activities that are far from uniformity that will attract tourists' curiosity.

As with any research, there are some limitations in this research. As the most important limitations of this research; it can be stated that it covers only the foreign tourists coming to the Antalya destination and that it has been made by sampling method in a certain time interval. In future researches, it can be suggested to conduct studies that test the destination image with different premises and results and provide the opportunity to compare with different samples. In addition, since the tourism level of the Antalya region is in the maturity stage, comparisons can be made by examining the destination image in regions with different tourism levels (beginning, development, and fall).

\section{References}

Aksu, A. A., Caber, M., \& Albayrak, T. 2009. Measurement of the Destination Evaluation Supporting Factors and their Effects on Behavioral Intention of Visitors: Antalya Region of Turkey. Tourism Analysis, 14(1), 115-125

Alcaniz, E. B., Garcia, I. S., \& Blas, S. S. 2009. The functional-psychological continuum in the cognitive image destination: a confirmatory analysis. Tourism Management, 30, 715-723.

Alpar, R. 2013. Uygulamalı çok değişkenli istatistiksel yöntemler (4th ed.). Ankara: Detay Publishing.

Antalya Governorate 2019. Antalya Governorate Airport Civil Administration Directorate Statistical Information, https://www.turizmajansi.com/haber/antalya-2019-da-kac-turist-agirladi-h34848.

Backman, S. J., \& Crompton, J. L. 1991. The usefulness of selected variables for predicting activity loyalty. Leisure Science, 13, 205-220.

Baloglu, S. 2001. An investigation of a loyalty typology and the multidestination loyalty of international travelers. Tourism Analysis, 6(1), 41-52.

Baloglu, S., \& Mangaloglu, M. 2001. Tourism destination images of Turkey, Egypt, Greece and Italy as perceived by us-based tour operators and travel agents. Tourism Management, 22, 1-9.

Baloglu, S., \& McCleary, K.W. 1999. A model of destination image formation. Annals of Tourism Research, 26(4), 868-897.

Baloglu, S., \& Uysal, M. 1996. Market segments of push and pull motivations: a canonical correlation approach. International Journal of Contemporary Hospitality Management, 8(3), 32-38.

Beerli, A., \& Martin, J. 2004. Factors influencing destination image. Annals of Tourism Research, 31(3), 657-681.

Berlyne, D. E. 1960. Conflict, Arousal and Curiosity. New York: McGraw-Hill.

Bigne, J. E., Sanchez, I., \& Sanchez, J. 2001. Tourism image, evaluation variables and after purchase behaviour: inter relationship. Tourism Management, 22, 607-616.

Blas, S. S., \& Carvajal-Trujillo, E. 2014. Cruise passengers' experiences in a mediterranean port of call. The case study of Valencia. Ocean \& Coastal Management, 102, 307-316.

Buhalis, D. 2000. Marketing the competitive destination of the future. Tourism Management, 21(1), 97-116.

Cardoso, L., Dias, F., Filipe de Araujo, A. \& Andres Marques, M. I. 2019. A destination imagery processing model: Structural differences between dream and favourite destinations. Annals of Tourism Research, 74, 81-94.

Cervera, A., Schlesinger, W., Iniesta, A., \& Sanchez, R. 2012. Measurement of university image and impact on graduate identification and loyalty: An approach on the basis of beerli and diaz's model (2003). Revista Espanola de Investigacion de Marketimg ESIC, 16(2), 7-29.

Chen, C. F., \& Tsai, D. C. 2007. How destination image and evaluative factors affect behavioral intentions? Tourism Management, 28, 1115-1122.

Chen, J., \& Gursoy, D. 2001. An investigation of tourists' destination loyalty and preferences. International Journal of Contemporary Hospitality Management, 13(2), 79-85.

Chon, K. S. 1992. The role of destination image in tourism: An extension. Tourism Review, 47(1), 2-8.

Ciasullo, M. V., Tommasetti, R., Troisi, O., \& Vesci, M. 2019. Curiosity as Brazilian tourist motivation in visiting Europe. Brazilian Journal of Tourism Research. 13(3), 140-160.

Cohen, L., Manion, L., \& Morrison, K. 2017. Research methods in education (8th ed.). London, United Kingdom: Routledge.

Crompton, J. 1979. Motivations for pleasure vacations. Annals of Tourism Research, 4, 408-424. 
Çoban, S. 2012. The Effects of the image of destination on tourist satisfaction and loyalty: the case of Cappadocia. European Journal of Social Sciences, 29(2), 222-232.

Denstadli, J. M., \& Jacobsen, J. 2011. The long and winding roads: perceived quality of scenic tourism routes. Tourism Management, 32(4), 780-789.

Echtner, C. M., \& Ritchie, J. R. B. 1991. The meaning and measurement of destination image. Journal of Tourism Studies, 2(2), 2-12.

Fornell, C., \& Larcker, D. F. 1981. Evaluating structural equation models with unobservable variables and measurement error. Journal of Marketing Research, 18(1), 39-50.

Gallarza, M.G., Saura, I.G., \& Garcia, H.C. 2002. Destination image towards a conceptual framework. Annals of Tourism Research, (29)1, 56-78.

Hair, J., Black, W., Babin, B., \& Anderson, R. 2014. Multivariate Data Analysis. 7th Edition. Pearson New International Edition.

Hernandez-Lobato, L., Solis-Radilla, M. M., Moliner-Tena, M. A., \& Sanchez-Garcia, J. 2006. Tourism destination image, satisfaction and loyalty: a study in Ixtapa-Zihuatanejo, Mexico, Tourism Geographies, 8(4), 343-358.

Ho, R. 2014. Handbook of univariate and multivariate data analysis with IBM-SPSS. Newyork: Chapman and Hall/CRC.

Howie, F. 2004. Managing the tourist destination. London: Thomson Learning.

Hu, L. T., \& Bentler, P. M. 1999. Cutoff criteria for fit indexes in covariance structure analysis: Conventional criteria versus new alternatives. Structural Equation Modeling, 6,1-55.

Hung, K., \& Petrick, J. F. 2011. The role of self and functional congruity in cruising intentions. Journal of Travel Research, 50(1), 100-112.

Hunt, J. D. 1971. Image: A factor in tourism. Colorado: Colorado State University Press.

Hussain, K., \& Kumar, J. 2015. Destination perception and loyalty: exploring the difference between local and foreign tourists. Journal of Tourism, 16(2), 27-42.

Inanır, A. 2019. Turistik destinasyon yönetiminde paydaşlar arası ilişkiler: Göller Yöresi örneği. Journal of Turkish Tourism Research, 3(3): 517-541.

Inanır, A. 2018. Destinasyon yönetimi kapsamında paydaşlar arası ilişkiler Göller Yöresi örneği. (doctoral thesis) Akdeniz University, Institute of Social Sciences. Antalya.

Kalaycı, Ş. 2014. SPSS uygulamalı çok değişkenli istatistik teknikleri. (6th ed.). Ankara: Asil Publishing.

Kim, H., \& Richardson, S. L. 2003. Motion picture impacts on destination images. Annals of Tourism Research, 30(1), 216-237.

Kline, R. B. 2011. Principles and practice of structural equation modeling (3th ed.). New York: The Guilford Press.

Lam, T., \& Hsu, C. 2006. Predicting behavioral intention of choosing travel destination. Tourism Management, 27(4), 589-599.

Lee, C. K., Lee, Y. K., \& Lee, B. K. 2005. Korea's destination image formed by the 2002 World Cup. Annals of Tourism Research, 32(4), 839-858.

Leisen, B. 2001. Image segmentation: The case of tourism destination. Journal of Service Marketing, 15(1), 49-66.

Litman, J. A., \& Spielberger, C. D. 2003. Measuring Epistemic curiosity and its diversive and specific components. Journal of Personality Assessment, 80(1), 75-86.

Liu, S., Wang S.Y., \& Qiu, W. 2003. Mean variance skewness model for portfolio selection with transaction costs, International Journal of Systems Science, 34(4),255-262.

Loewenstein, G. 1994. The psychology of curiosity: A review and reinterpretation. Psychological Bulletin, 116(1), 75-98.

Lopes, S. D. F. 2011. Destination image: origins, developments and implications. Revista de Turismo y Partimonio Cultural, PASOS, 9(2), 305-315.

Lumley, T., Diehr, P., Emerson, S., \& Chen, L. 2002. The importance of the normality assumption in large public health data sets, Annual Review of Public Health, 23, 151-169.

Marine-Roig, E. 2019. Destination Image Analytics Through Travellers-Generated Content. Sustainability, 11, 3392; doi:10.3390/su11123392.

McDowall, S., \& Ma, E. 2010. An analysis of tourists' evaluation of Bangkok's performance, their satisfaction, and destination loyalty: comparing international versus domestic Thai tourists. Journal of Quality Assurance in Hospitality \& Tourism, 11(4), 260-282.

Oppermann, M. 2000. Tourism loyalty. Journal of Travel Research, 39(1), 78-84. 
Pan, Y., Sheng, S., \& Xie, F. T. 2012. Antecedents of customer loyalty: An empirical synthesis and reexamination. Journal of Retailing and Consumer Services, 19, 150-158.

Phau, P. L., Lee, S., \& Quintal, V. 2013. An investigation of push and pull motivations of visitors to private parks: The case of Araluen botanic park. Journal of Vacation Marketing, 19(3), 263-284.

Prayag, G. 2008. Image, satisfaction and loyalty-the case of Cape Town. An International Journal of Tourism and Hospitality Research, 19(2), 205-224.

Rajesh, R. 2013. Impact of tourist perceptions, destination image and tourist satisfaction on destination loyalty: A conceptual model. Revista de turismo y Patrimonio cultural PASOS, 11(3): 67-78.

Ramkissoon, H., Uysal, M., \& Brown, K. 2011. Relationship between destination image and behavioral intentions of tourists to consume culturel attractions, Journal of Hospitality Marketing \& Management, 20(5), 575-595.

Raykov, T., \& Marcoulides, A. G. 2006. A First course instructural equation modeling (2th Edition). New Jersey, USA: Lawrence Erlbaum Inc.

Riley, M., Niininen, O., Szivas, E. E., \& Willis, T. 2001. The Case For Process Approaches in Loyalty Research in Tourism. International Journal of Tourism Research, 3, 23-32

Rittichainuwat, B. N. 2008. Responding to disaster: Thai and Scandinavian tourists' motivation to visit Phuket, Thailand. Journal of Travel Research, 46, 422-432.

Rodrigues Soares, J. R., Carvalho, C. E., \& Santos, X. M. 2019. Perceived image and loyalty in academic tourism. Anales De Geografía De La Universidad Complutense, 39(2), 485-506

Rodriguez del Bosque, I., \& San Martin, H. 2008. Tourist satisfaction: a cognitive affective model. Annals of Tourism Research, 35(2), 551-573.

San Martin, H., \& Rodriguez, I. A. 2008. Exploring the cognitive-affective nature of destination image and the role of psychological factors in its formation. Tourism Management, 29(2), 263-277.

Schumacker, R. E., \& Lomax, R. G. 2010. A beginner's guide to structural equation modeling, New York: Taylor \& Francis Group.

Scott, D. 1996. A comparison of visitors motivations to attend three urban festivals. Festival Management \& Event Tourism, 3, 121-128.

Selin, S. D. R., Howard, E. U., \& Cable, T. 1988. An analysis of consumer loyalty to municipal recreation programs. Leisure Science, 10, 210-223.

Sharpley, R. 2008. Tourism, Tourist and Society. Huntingdon: ELM.

Slope Test 2020. http://www.jeremydawson.com/slopes.htm (11 April 2020).

Spielberger, C. D., \& Starr, L. M. 1994. Curiosity and exploratory behavior. H. F. O. Neil Jr., \& M. Drillings (Eds.). Motivation: theory and research (221-243). New Jersey: Lawrence Erlbaum Associates, Inc.

Sun, X., Geng-Qing, Chi, C., \& Xu, H. 2013. Developing destination loyalty: the case of Hainan Island. Annals of Tourism Research, 43, 547-577.

Tasci, A. D. A. 2006. Visit Impact on Destination Image. Tourism Analysis, 11(5): 297-309.

Tasci, A. D. A., Holecek, D. F. 2007. Assessment of image change over time: The case of Michigan. Journal of Vacation Marketing, 13(4), 359-369.

Tasci, A. D. A., Gartner, W. C., \& Çavuşgil, S. T. 2007. Conceptualization and operationalization of destination image. Journal of Hospitality \& Tourism Research, 31(2), 194-223.

Tasci, A. D. A., \& Gartner, W.C. 2007. Destination image and its functional relationships. Journal of Travel Research, 45(4), 413-425.

Tasci, A. D. A. 2009. Social Distance: The Missing Link in the Loop of Movies, Destination Image, and Tourist Behavior? Journal of Travel Research, 47(4), 494-507.

Tosun, C., \& Jenkings, C. L. 1996. Regional planning approaches to tourism development: The case of Turkey. Tourism Management, 17(7), 519-531.

Vincent, C. T. P. 2018. Amateur versus professional online reviews: Impact on tourist' intention to visit a destination. Tourism: An International Interdisciplinary Journal, 66(1), 35-51.

Wang, B., \& Wu, C. Y. 2011. The Effect of destination image on destination loyalty Management Review, 23(11), 83-91.

Wang, C. Qu, H., \& Hsu, M. K. 2016. Toward an integrated model of tourist expectation formation and gender difference. Tourism Management, 54, 58-71.

Yılmaz, Y., Yılmaz, Y., Tarcan İçigen, E., Ekin, Y., \& Demirel Utku, B. 2009. Destination image: A comparative study on pre and post trip image variations. Journal of Hospitality Marketing \& Management, 18, 461-479.

Yoon, Y., \& Uysal, M. 2005. An examination of the effects of motivation and satisfaction on destination loyalty: A structural model. Tourism Management, 26, 45-56. 
Zhang, H., Fu, X., Cai, L. A. \& Lu, L. 2014. Destination image and tourist loyalty: A meta analysis.

Tourism Management, 40, 213-223.

\section{Appendix}

\begin{tabular}{|c|c|}
\hline & Destination Image \\
\hline DI1 & Tourist information is wide and adequate \\
\hline DI2 & Tourist signs are appropriate. \\
\hline DI3 & Tourist services (tourist ofice, shuttle bus etc.) provided sufficient \\
\hline DI4 & Tourist attractions/places to visit are varied. \\
\hline DI5 & There is a rich and varied gastronomy/a wide variety of restaurants. \\
\hline DI6 & There is a good variety of shops and many facilities for shopping. \\
\hline DI7 & There are enough leisure activities \\
\hline DI8 & It is a quiet city. \\
\hline DI9 & Residents are friendly and welcoming. \\
\hline DI10 & The weather is nice. \\
\hline DI11 & $\begin{array}{l}\text { There is a good urban environment with low levels of environmental pollution (traffic, noise, } \\
\text { fumes, etc.). }\end{array}$ \\
\hline DI12 & Street/area cleaning is optimal. \\
\hline DI13 & Shops have a good price equality relationship. \\
\hline \multirow[t]{2}{*}{ DI14 } & Restaurants have a good price equality relationship \\
\hline & Destination Curiosity \\
\hline CUR1 & I want to know more about Antalya. \\
\hline CUR2 & I want to receive some more information about Antalya. \\
\hline CUR3 & Antalya has the attractions that I like \\
\hline CUR4 & Antalya has a unique atmosphere that attracts me \\
\hline CUR5 & Travel to Antalya can let me learn some interesting things \\
\hline \multirow[t]{2}{*}{ CUR6 } & Travel to Antalya can let me try some interesting things \\
\hline & Destination Loyalty \\
\hline LOY1 & I will recommend Antalya to someone that seeks my advice. \\
\hline LOY2 & I will encourage friends and relatives to visit Antalya. \\
\hline LOY3 & I will say positive things about Antalya to other people. \\
\hline LOY4 & I would choose to travel to Antalya even if its prices should increase somewhat \\
\hline LOY5 & I will be back to Antalya in the next three years. \\
\hline LOY6 & Within the next three years, I would Antalya more than I would revisit any other destination. \\
\hline
\end{tabular}

Recibido: 